\title{
Neo-Kantçı Ahlak Felsefesi Bağlamında Sosyal Demokrat Revizyonizm Tartışmaları
}

\section{Social Democratic Revisionism Debates in the Context of Neo- Kantian Moral Philosophy}

\author{
Onur Alp Yilmaz ${ }^{1}$
}

${ }^{1}$ (Öğr. Gör.), Işık Üniversitesi, Fen Edebiyat Fakültesi, İnsan Toplum Bilimleri Bölümü, İstanbul, Türkiye

\section{ORCID: O.A.Y. 0000-0001-6158-7165}

Sorumlu yazar/Corresponding author: Onur Alp Yılmaz

Işık Üniversitesi, Fen Edebiyat Fakültesi, İnsan Toplum Bilimleri Bölümü, İstanbul, Türkiye

E-posta/E-mail: onuralp.yilmaz91@gmail.com

Başvuru/Submitted: 19.11.2020 Revizyon Talebi/Revision Requested: 25.01.2021

Son Revizyon/Last Revision Received: 02.03.2021

Kabul/Accepted: 04.03.2021

Atıf/Citation: Yilmaz, Onur Alp. "Neo-Kantçı Ahlak Felsefesi Bağlamında Sosyal Demokrat Revizyonizm Tartışmaları. Felsefe ArkiviArchives of Philosophy, 54 (2021): 97-116. https://doi.org/10.26650/arcp.828061

\section{ÖZET}

Kant, bir 18. yüzyıl filozofu olmasına karşın, görüşleri kendi döneminde olduğu kadar sonraki yüzyıllarda da yankı uyandırmış ve birçok kişiye ilham kaynağı olmuştur. Kant'ın ahlak felsefesi üzerinden yürüttüğü tartışmalar, onun siyaset felsefesi de dahil olmak üzere tüm felsefesinin mihverini oluşturmuştur. Kant'ın birey odaklı felsefesi, bir yandan liberal ideolojinin takipçileri arasında tartışma konusu olurken, diğer yandan da 19. yüzyılın ikinci yarısından itibaren sosyal demokratlar arasında tartışmalara konu olmuştur. Almanya'da Lassalle'le başlayan bu tartışmalar, Fabian Hareketi'yle sürmüş ve Bernstein'le doruk noktasına ulaşmıştır. Bu hareketler, Ortodoks Marksizmden koptukça daha etik merkezli bir noktaya evrilmiş ve adeta neo-Kantçı bir projeye dönüşmüştür. Bu dönüşümü besleyen ve sosyal demokrat revizyonizmin temellerini oluşturan tartışmaysa Bernstein ve Kautsky arasında yaşanmıştır. Kant ve Marx'ın ahlak anlayışlarını mevcut toplum üzerinden tartışan ikili, buradan sosyal demokrasiye bir gelecek planı, iktidar stratejisi ve toplum tahayyülü de çıkarmak için çabalamışlardır. Bir yandan daha muğlak bir ahlak tanımı olan Marx'ın ve dolayısıyla Marksizmin ahlak görüşleri iki tarafından yorumlanırken, diğer yandan da Kant'ın ahlak anlayışııın sosyal demokrasideki rolünün ne olması gerektiği tartışılmıştır. Bu bağlamda bu çalışma, öncelikle Kantçı ve Marksist ahlak anlayışlarını karşılaştırarak birbirinden ayrıldığı noktaları gözler önüne sermiştir. İkinci olarak bu çalışmada, sosyal demokrasinin hangi alanlarda Kantçı felsefeyi takip ettiği, Lassalle, Fabiancı Hareket, Kautsky ve Bernstein'in görüşleri tartışıımıştır.

Anahtar Kelimeler: Kant, Marksizm, Ahlak Felsefesi, Revizyonizm, Siyaset Felsefesi

\section{ABSTRACT}

The views of the eighteenth-century philosopher, Immanuel Kant, resonated in his time as well as in the following centuries and inspired several subsequent philosophers. Kant's debates on moral philosophy formed the axis of his entire philosophy, including the praxis of his own political philosophy. While, on one hand, Kant's individual-oriented philosophy has been the subject of discussion among the followers of liberal ideology, on the other hand, it has been the subject of discussion 
among social democrats since the second half of the nineteenth century. These discussions, which started with Lassalle in Germany, continued with the Fabian Movement and reached their peak with Bernstein. As these movements broke away from orthodox Marxism, they evolved into a more ethically-centered point and transformed into a neo-Kantian project. The debate that enriched this transformation and formed the basis of social democracy as an ideology and political praxis took place between Bernstein and Kautsky. The duo, who discussed Kant and Marx's understandings of morality by focusing on the existing society, tried to instigate a plan, strategy of power, and social strategy of ruling power. On one hand, the moral views of Marx form a more ambiguous definition of morality, and thus, the wider meaning of Marxism was interpreted by the duo; on the other hand, the role of Kant's moral understanding in social democracy was discussed. In this context, this study first compares the Kantian and Marxist understanding of ethics, revealing the points where they differ from each other. Second, in this study, areas of social democracy following the Kantian philosophy, views of Lassalle, the Fabianist Movement, and the work of Kautsky and Bernstein are discussed.

Keywords: Kant, Marxism, Moral Philosophy, Revisionism, Political Philosophy

\section{EXTENDED ABSTRACT}

Although Marxism has been an ambiguous philosophy on morality, there is still no consensus among Marxist philosophers in this field. Therefore, discussions on Marxist morality have a vast literature available to understand how Marx focuses on morality and the existent moral values. It is possible to classify the philosophers' ideas into two groups depending on their understandings of Marxist morality. While the first group believes that Marx's philosophy always included a moral philosophy, the second claims that he understood morality as an obstacle to overcome in his age of maturity. In addition to these groups, the ideology of social democracy, which derives in part from Marxism, discussed Marx's understanding of morality and decided on how to approach the existent moral values. As a result of the discussions on moral philosophy between social democrat ideologists, Bernstein and Kautsky, the social democratic bloc disassociated itself not only organizationally but also ideologically.

Although Bernstein did not ignore class-based politics, he aimed to transform social democracy into an ethics-based ideology, which can be described as a neo-Kantian moral and political view. The basis of his new idea was integrating class-based politics into the existing society by welcoming individual rights and freedoms. In other words, his idea of ethics-based class politics did not prioritize the revolution, but action. His main motivation was to reform the capitalist system without violence. Alternatively, Kautsky still prioritized Marxist arguments. He strongly supported that the transfer of the means of production is a must, believing that it is the core of socialism. Kautsky approached social morality as a pressure instrument of dominant classes, namely, the bourgeoisie, while Bernstein remarked that no one can destroy civil society. In other words, contrary to Bernstein's view that individuality can develop only in a free society, Kautsky believed that free will is not possible in a class society that is inherently morally manipulated. As seen above, their differences on moral philosophy directly affected their strategy to reach the ideal society, political system, and state. 
Moral and ethical preferences also specify a social transformation method, which legitimatizes or illegitimatizes the violence required to establish a left-oriented regime. Bernstein's idea marginalized and illegitimatized violence as it called on the bourgeoisie to transform the system in favor of the proletariat. However, Kautsky objected to Bernstein's idea as he believed that the proletariat would reject a possible alliance with the bourgeoisie. He always supported a homogeneous proletariat. Therefore, it is possible to mention that the continuous discussion between orthodox Marxist and social democrats is not only political but also philosophical. In other words, at the core of discussions is philosophical preference: a Kantian morality or the Marxist one. While the former categorically opposes the dictatorship, including the proletariat variant, the latter aims to establish a proletariat dictatorship by overturning bourgeois democracy. The former aims to reform the system to create a more equal society, and the latter aims to do away with the system to create an equal one. The former prioritizes the need to create an awareness of citizenship, while the latter tries to reach an international class consciousness.

In this context, this study primarily discusses social democratic revisionism and orthodox Marxist antirevisionism on the philosophical side to understand how the philosophical basis affects ideological preferences, which include power strategy, ideal social, and institutional imaginations. Second, this study aims to demonstrate in which subfields social democrats are differentiated under the names of revisionists and antirevisionists. Finally, this study offers a conceptual perspective historically from Lassalle and the Fabian Movement's theoretical frameworks to Kautsky and Bernstein's discussion to determine the steps of the social democratic roadmap toward neo-Kantianism. 


\section{Giriş}

18. yüzyılın en önemli filozoflarından olan Kant'a kadar felsefe, insan zihninin nesne çerçevesinde şekillendiğine inanan bir anlayışın egemenliği altında hüküm sürmüştür. Kant ise bu yaygın kanıyı tersine çevirerek, nesnenin insan zihni çevresinde şekillendiği hipotezini ortaya atmıştır. Bu noktadan sonra Kant'ın tüm felsefesi, insan zihnine yüklediği bu kurucu rol üzerinden ilerlemiştir. Kant'ın rasyonalizm ve ampirizmin birleşiminden elde ettiği sentezle kurduğu kendine ait kritik felsefe de yine kendi çağının devrim niteliği taşıyan atılımlarından biri olmuştur. Kant, bu sentezine rağmen numenler alanı olan metafizik alana geçildiğinde, kendi kritik yönteminin imkansız hâle geldiğini düşünmüştür. Çünkü ona göre, bu alanda akıl ve deneyimin sentezi olarak ortaya çıkan bilgiye ulaşmak mümkün değildir. Bu alan, duyuların ötesine geçtiği için akıl ve duyuların ortak çalışmasını burada yürütmek Kant tarafından imkânsız olarak algılanmıştır. ${ }^{1}$

Kant'ın etik anlayışının mihverine koyduğu düşünceyse özgürlüktür. Ancak Kant’ın özgürlük anlayışı, ödevlerden bağımsız bir anlayış olmanın aksine; ödevlerle simbiyotik ilişki içinde olan bir anlayışı temsil eder. Kant'ın ödev etiği dini bir içerikle bulanmış bir vaziyette değildir, aksine sekülerleştirilmiştir. Kant, ne Tanrı tarafından koyulan yasanın ne de doğa tarafından belirlenen zorunlulukların insan davranışlarını belirlemesiyle insanların özgür kılınamayacağını söyler. Çünkü her iki vaziyette de insan davranışını belirleyen şey, dışsal bir faktörün zorlamasıyla gerçekleşecektir. Kant’a göre, insan davranışını iyiye yönlendirecek şey yalnızca onların kendi koydukları ödevlerin peşinden gitmeleri olabilir. Kant'ın inancına göre, insanların ortak iyileri son tahlilde örtüşecek ve insanlar iyi iradelerinin yönlendirmesiyle iyi olanın peşinden koşacaklardır. ${ }^{2}$ İnsanların duygularının, kişilerin anlık ihtirasları ya da uzun erimli hedefleri doğrultusunda dürtüler yoluyla belirlenebildiğini tespit eden Kant, bu yüzden ahlak felsefesini usa dayandırma yolunu tercih eder. ${ }^{3}$ Kant, bu felsefesini evrensel kılacak şeyin insanların eylerken, kendisini evrensel bir yasa yapıcı olarak tahayyül etmesi olacağını ifade etmiş ve kişilerin kendilerini ve eylemlerini bir istisna olarak algılamamaları gerektiğini belirtmiştir. ${ }^{4}$ Onun ahlak felsefesi; bireylerin adalet, eşitlik ve özgürlüğe duyduğu ebedi özlem fikri çerçevesinde şekillenmiştir ve buna bulduğu çözümse insanlığın hedeflenmesi ve bu tartışmaların ana odak noktasını oluşturması olmuştur. Onun bahsettiği kavramların, sosyal demokrasinin evrensel ilkeleri olması, bu ideolojiyi Ortodoks Marksist düşünceden ayıran ideologların ilgisini çekmiş ve bu, Kantçı felsefeden yararlanmalarıyla sonuçlanmıştır. Öyle ki, onları Marksist düşünceden uzaklaştıran her adım, Kantçı felsefenin sınırlarına bir adım daha yaklaştırmıştır.

$\mathrm{Bu}$ çalışma literatüre sosyal demokrasinin revizyonist fikirlerinde Kantçı felsefenin izlerini sürerek katkı sunmayı amaçlar. Literatürde, Marksizm ve Kant felsefesini karşılaştıran birtakım

\footnotetext{
Manfred Kuehn, Immanuel Kant, (İstanbul: Türkiye İş Bankası Kültür Yayınları, 2011), 123

Hannah Arendt, “Kant'ın Siyaset Felsefesi Üzerine Notlar”, çev. Yasemin Tezgiden Cogito41-42 (2005), 351.

Hannah, Arendt, "Kant'ın Siyaset Felsefesi Üzerine Notlar," 352.

Immanuel Kant, Gelecekteki Her Metafiziğe Prolegomena, çev. Ionna Kuçaradi ve Yusuf Örnek, (Ankara: Türkiye Felsefe Kurumu Yayınları, 1995), 48-50.
} 
eserler bulunmasına karşın, ${ }^{5}$ bu çalışmalar bir sosyal demokrasi karşılaştırması yapmaktan ziyade Ortodoks Marksizme kapitalizm ve dolayısıyla liberalizm karşısında ahlaki bir üstünlük sağlama gayesindeki çalışmalardır. Ayrıca, sosyal demokrasi ve özellikle Bernstein üzerindeki Kant etkisinden bahseden çeşitli çalışmalar olsa da bu tartışmalar ${ }^{6}$ da meselenin derinlemesine bir incelemesini yapmayıp, yalnızca yüzeysel bir tespit niteliği taşırlar. Son olarak, yine klasik liberalizm, Ortodoks Marksizm gibi ideolojilerle sosyal demokrasiyi karşılaştıran eserler olmasına karşın, ${ }^{7}$ bu çalışmalar da sosyal demokrasi ve Kant arasındaki izdüşümlere odaklanmaktan ziyade, sosyal demokrasinin bu ideolojilere karşı rüştünü ispatlama gayesindedirler. Dolayısıyla, bir 18. yüzyıl filozofu olan Kant’ın bir sonraki yüzyılda başlayan revizyonizm tartışmalarında erken dönemden itibaren yarattığı etkiyi ve yine 20. yüzyıla da sarkan bu fikirleri kavramak açısından önemli görünmektedir. Ek olarak, Kant’ın sosyal demokrat ideoloji üzerindeki etkilerini incelemek, sosyal demokrasinin hangi noktalarda Marksizmden kendisini soyutlayıp Kant'in felsefesine yaklaştığını görmek açısından da önem taşımaktadır, ki bu yakınlaşma aslında sosyal demokrasinin liberalizmle ve burjuva demokrasisiyle barışma sürecini de temsil etmektedir.

Çalışma üç bölümden oluşmaktadır. İlk bölümde, Marksist ahlak anlayışından başlayarak, Kant’ın ahlak görüşleri üzerinden bir arka plan verildikten sonra, sosyal demokrat revizyonizm tartışması için bir fikirsel temel aktarılmıştır. İkinci bölümde, sosyal demokrat revizyonizm üzerinde, Kant'ın ahlak yasası çerçevesinde şekillenen siyaset felsefesinin izleri karşılaştırmalı bir perspektiften incelenmiştir. Sonuç bölümündeyse sosyal demokratların Kant üzerinden revizyonizmlerine çizdikleri rota Kautsky ve Bernstein üzerinden açıklanmış ve yarattıkları meşruiyet tartışılmıştır.

\section{Marksizm ve Kantçılı̆̆ın Temel Ahlak Görüsşleri}

Marksizmin ahlak felsefesini anlamak için Marx’'n ahlakla ilgili görüşleri, 1845'te kaleme alınan Alman İdeolojisi ve öncesi olmak üzere iki döneme ayrılabilir. Çünkü Marx, 1845 sonrası yazdıklarında öncülü olan filozofların ahlak felsefesi alanında yazdıklarını pejoratif bir üslupla kritik ederken, öncesinde yazdıklarında ise yabancılaşmadan insan doğasının gelişimine kadar birçok ahlak temelli konuya değinmiştir. Bu noktada da Marx üzerine yazılanları iki gruba ayırmak mümkündür; Brenkert ve Peffer gibi isimleri kapsayan bir grup Marx’'n felsefesinin her zaman ahlakı içerdiğinden bahsederken; diğer yandan Althusser ve Lefebvre gibi isimler, Marx’ın gençlik dönemi yazılarından sonra ahlakı, aşılması gereken bir kambur olarak algıladı̆̆ından bahsederek, bunu Marx’’n anti-idealist (hümanist) dönemi olarak görmüştürler.

İlk gruptakilerin bakış açısına göre, ikinci gruptakilerin Marx’ta ahlak görüşünün olmadığını düşünmelerinin nedeni, Marx’ın ahlakın sonuçlarıyla değil nedenleriyle ilgilenmesinden kaynaklandığını ve onun sonuca bakarak "en yüksek iyi”yi görmek gibi bir yola başvurmaması

5 Bkz. Kojin Karatani, Transkritik Kant ve Marx Üzerine, (İstanbul: Metis Yayınları, 2017)

6 Bkz. Deniz Kavukçuoğlu, Sosyal Demokraside Temel Eğilimler, (İstanbul: Cumhuriyet Kitapları, 2003) ve İhsan Kamalak, "Sosyal Demokrasiyi Tanımlamak: Eduard Bernstein’in Yaklaşımı Üzerinden Bir Deneme İlkeleriyle Sosyal Demokrasi”, Sosyal Demokrasi Okumaları İçinde, Der. İbrahim Sarıtaş (Ankara: Orion, 2012)

7 Yurdagül Fincancı, Günümüzde Sosyal Demokrasi, (İstanbul: TÜSES Vakfı Yayınları, 1993) 
ve buradan bir ahlak yasası çıkarmaması ile ilişkilendirilmiştir. Hatta Marx, böyle bir davranışın içinde olanları "ahlaki vaaz" vermekle eleştirmiştir. ${ }^{8}$ Brenkert’in de ifade ettiği gibi Marx, prensiplere ve yasalara odaklanan bir ahlak anlayışını ikinci plana itmiş ve bunun yerine mevcut sistemin eleştirisi içinde mevcut olan ahlakın da eleştirisi ve dönüşümüne odaklanmıştır. ${ }^{9}$ Brenkert, Marx' in soyut ve kuramsal olanla değil, somut ve pratik olanla ilgilendiğini ifade etmiştir. ${ }^{10} \mathrm{Bu}$ doğrultuda fikir beyan eden bir diğer kişi olan Peffer ise Marx’’n bir ahlak doktrineri olmamakla beraber, her zaman bir ahlak normunu satır aralarında görmenin mümkün olduğunu ifade etmiş ve Marx’ın ahlak anlayışını 1841-1843 yılları arasında yazlıklarıyla "Radikal liberalist" olduğu ilk dönem, 1843 'te yazdıklarıyla "Devrimci Hümanist” olduğu ikinci dönem, 1844'te yazdıklarıyla “Özgün Marksist” olduğu üçüncü dönem, 1844 ve 1847 aralığında yazdıklarıyla “Geçiş Dönemi” yaşadığ 1 dördüncü dönem ve 1848 'den ölümüne kadar uzanan periyotta yazdıklarındaki ahlak görüşlerinden bahsettiği beşinci dönem olmak üzere toplam beş dönemde sınıflandırmıştır. ${ }^{11}$ Peffer, Marx’ın başlarda bireyin amaçlarını seçebilmekte özgür olduğu gibi Kant'tan mülhem, liberal ilkelere uzak olmayan ve daha birey merkezli bir ahlak anlayışını benimserken, gitgide ahlakın toplumsal boyutlarına, somut olana ve pratiğe yönelmiş ve özellikle 1848 'den sonraki çalışmalarında hiçbir sapma olmadan doğrudan iktisat ve sosyolojiyi çalışmalarının mihverine koyduğunu ifade etmiştir. ${ }^{12}$

İkinci gruptakilerin bakış açısına göre ise Althusser'de somutlaştığı üzere, ahlakın aşılması gereken bir kambur olduğu fikri Marx’ta özellikle Alman İdeolojisi eserinden sonra ortaya çıkmış bir fikirdir. Ona göre Marx’ın bu dönem öncesi yılları, spekülatif felsefeyle içli dışlı olduğu yıllar olmakla beraber, bu eserin ardından Marx, Hegel'in diyalektiği, idealizmiyle (hümanizm) saptırdığını ifade ederek eleştirmeye başlamıştır. ${ }^{13}$ Benzer doğrultuda görüşler taşıyan Lefebvre ise Marksizmin bireyin arzularının esiri olduğunu ve kendisini dizginleyebileceği bir sınırın dahi olmadığını belirterek, "burjuva ahlakı" olarak tanımladığı liberal ahlak anlayışına negatif baktığını ifade etmiştir. Marksizme göre, ahlak olarak nitelendirilen şey aslında bu kuralları, yaptırım gücü (devlet) veya teolojik-metafizik öğeler aracıllı̆ıyla toplumu manipüle ederek kendi lehine kullanması ve gerçeği çarpıtmasından başka bir şey değildir. ${ }^{14} \mathrm{Bu}$ ahlak anlayışı, her tür yeni fikir akımına kapalı olarak, hatta yer yer bu yeni fikir akımlarının izinden gidenleri günahkâr sayarak, kendi sürekliliğini sağlamaktadır. Nitekim bu dinle harmanlanmış ahlak anlayışı, acı ve yoksulluk karşısında sabır ve sebatı başka bir evrende ödüllendirilecek bir erdem olarak lanse etmiştir. ${ }^{15}$ Marksist anlayışa göre, ahlakı kutsayan bu tavır, mevcut düzenin meşrulaştırmasının en dâhiyane yolu olmuştur. Marksistler tarafından, yalnızca ahlaki normları koyanların faydasına olduğuna inannılan bu ahlak anlayışının bizatihi kendisi ahlaksızlık olarak yorumlanmıştır.16 Marksistler, yalnızca ahlakın değil, hukukun da bahsi geçen muktedirlerin, egemen sınıfların

8 George G. Brenkert, Marx’ın Özgürlük Etiği, çev. Yavuz Alogan, (İstanbul: Ayrıntı, 1998), 22.

9 Brenkert, Marx’in Özgürlük Etiği, 31.

10 A.g.e., 43.

11 R. G. Peffer, Marksizm, Ahlak ve Toplumsal Adalet, çev. Yavuz Alogan, (İstanbul: Ayrıntı, 2001), $45-86$.

12 Peffer, Marksizm, Ahlak ve Toplumsal Adalet, 73-75.

13 Louis Althusser, Marx İçin, çev. Işık Ergüden, (İstanbul: İthaki, 2015), 117-118.

14 Henri Lefebvre, Sosyalist Dünya Görüşü: Marksizm, çev. Doğan Görsev, (İstanbul: Yordam, 2014), 65-66.

15 Lefebvre, Sosyalist Dünya Görüşü: Marksizm, 67.

16 A.g.e., 69. 
çıkarlarını korumak için, onların tahakkümlerini meşru kılmak için ortaya çıkan ve ilerlemeye ket vuran bir araç olduğunu iddia etmiştirler. ${ }^{17}$ Tüm bu araçlar modern çağın sınıflı toplumlarında burjuvazinin çıkarlarına hizmet ederken, proletarya da kendisiyle özdeşleştirdiği onurlu yoksullukla ve emeğiyle para kazanmakla kendisini avutmuştur.

Ancak yine kapitalizmin tüm yükünü sırtlanan bu sınıf, öz-yabancılaşmasını kırdığı anda, tüm bu yabancılaşılan kavramlardan hem kendisini hem de toplumu kurtarabilecek yegane gücü temsil etmiştir. ${ }^{18}$ Hedef, rolü önceden tanımlanmış ve manipüle edilmiş, pozitivizmin işbölümü şablonuyla bulunduğu toplumsal katmana hapsettiği işçi sınıfını uykusundan uyandırıp bütüncül insana (homme total) ulaşmaktır. ${ }^{19}$ Bunun yolu da insanların varlıklarını belirleyen şeyin bilinçleri değil, toplumsal varlıkları oldukları ön kabulünden geçmektedir. Başka bir ifadeyle, insanlar ahlak, hukuk gibi öğretileri kendi varlıklarının bir parçası olarak, doğal ya da doğuştan getirmemiş, toplum tarafından manipüle edilmeleri sonucunda bu kurallara adapte olmuşlardır. ${ }^{20}$ $\mathrm{Bu}$ yüzden, kapitalist toplumda burjuvazinin kendisini kayırmaya ve proletaryayı tahakküm atlına almaya yönelik sözde bireyciliğinden kurtulup; Marksist manada bir bireye, proletaryaya kendisini kusurlu hissettiren parça başı çalışma gibi uygulamalardan, teorik ve pratik düşünme kapasitelerini geliştirecek bir donanım sağlamaya ve homme totale ulaşmaya ihtiyaç vardır. ${ }^{21}$

Marx’'n genel olarak ahlak felsefesi olup olmadığıyla ilgilenen bu görüşlerin ortaklaştığı nokta, Marx’ın mevcut felsefeye getirdiği eleştirilerdir. Bu anlamda, bu görüşlerden bahsedildikten sonra Kant'in insan, ahlak, din, özgürlük, etik gibi alanlardaki fikirlerinden bahsetmek, sosyal demokrasinin Marksizmden hangi noktalarda farklılaştığını anlamak açısından faydalı olacaktır. İlk olarak Kant, Rousseaucu bir etkiyle insan-odaklı bir felsefi yorum geliştirme çabası içinde olmuştur. Bu çaba, Kant'ın ampirizm ve rasyonalizmin sentezini yapma çabasında vücut bulmuştur. ${ }^{22}$ Daha açık bir ifadeyle Kant, bilginin kaynağının akıl olduğu fikriyle, insan zihninin boş bir levha (Tabula Rasa) olarak dünyaya geldiği fikrinin bir sentezini yapmıştır. Aslında us ve deney-gözlemin birbiriyle çatışıyor görünen bu yorumunu; deneyden elde edilen bilgiye us vasıtasıyla form verilmesi olarak açıklamıştır. ${ }^{23}$ Kant'ın felsefi alanda yaptığı devrim, o döneme kadar insan aklının nesneyle bağdaştı̆̆ı iddia edilirken; onun bu hipotezi tahtından ederek, nesnenin insan zihniyle bağdaştığını söylemesi olmuştur. Kant’ın bu anlayışına göre, akıl, edilgen değil etken bir pozisyondadır. Alternatif bir beyanla Kant, bilginin insan zihninin bir ürünü olduğunu ve kaynağının da deneyimden geldiğini söylemiştir. Kant’a göre, aklın bilgiye yaptığı formel katkı da bu doğuştan getirilen a priori deneyimler vasıtasıyla olmaktadır. Buradan çıkardığı sonuç da Kant'ı, insanın zihninde kendisine özellikler yükleyebildiği ve kodlayabildiği şeyleri bilmeye muktedir olduğu sonucuna götürmüş ve buradan fenomenler ve numenler olmak üzere iki farklı alan ortaya çıkmıştır. ${ }^{24}$

17 Friedrich Engels ve Karl Marx, Felsefe İncelemeleri, çev. Cem Eroğul, (İstanbul: Yordam, 2017), 99.

18 Lefebvre, Sosyalist Dünya Görüşü: Marksizm, 71.

19 A.g.e., 74.

20 Engels ve Marx, Felsefe İncelemeleri, 99.

21 Lefebvre, Sosyalist Dünya Görüşü: Marksizm, 77.

22 Aysel Demir, Kant Ahlak Siyaset (Ankara: Siyasal Kitabevi, 2020), 13.

23 Demir, Kant Ahlak Siyaset, 14.

24 Immanuel Kant, Ahlak Metafiziğinin Temellendirilmesi, çev. Ioanna Kuçuradi, (Ankara: Türkiye Felsefe Kurumu, 1994), 85 . 
Kant, özne olan insanın bilgisi ya da etken olduğu sınırı fenomenler dünyası olarak belirlemiştir. Kant’ın "kendinde şeyler” olarak kategorize ettiği alansa numenlerin, metafiziğin alanıdır ve akıl-deneyim ikilisinin ürünü olan bilgi, bu alanda imkânsız hâle gelmiştir. Tanrı, ruh, evren ve maddenin yapısıyla ilgili olan bu alan, duyuların ve deneyimlerin dışına çıktığı için bu alanda insan, deneyimden yoksundur. Bu da aklı metafizik alanda deneyimden yoksun bir hâlde bırakır ve bu koşulda da bilgiye ulaşmak için gerekli sentezin ortaya çıkması imkânsız hâle gelir. Bu noktada da insanın bilgiden uzak, metafizik alanla ilgili, dinler dünyasıyla ilgili düşünce ve inanışları ortaya çıkar ve bunların hangisinin doğru olduğunu bilmek de imkânsızdır. ${ }^{25}$ Nitekim insan, metafizik alanla ilgili düşünceleriyle değil, ussal düşünceyle özgürlüğünün önündeki engelleri bertaraf edebilir. ${ }^{26}$

Kant, siyaset felsefesi de dâhil tüm felsefi görüşlerini üzerine oturttuğu ahlak felsefesine giden yolu, teorik ve pratik us olmak üzere iki temel ayak üzerine inşa etmiştir. Aslında bu ayrım, olan ve olması gereken arasındaki farktır. Olan, teorik usun alanını, fenomeni oluştururken, olması gerekense pratik usun alanını, numenler dünyasını oluşturur. Duyulardan beslenen "olan” ampiriktir ve insanı düşünme yeteneğine iten de odur (teorik us). ${ }^{27}$ Olması gerekense, insanı eylemde bulunma kuvvetini temsil eder ve duyulardan beslenmediği için de ampirik değildir (pratik us). ${ }^{28}$ Teorik cephe, insanı zorunluluğun bir parçası haline getirirken, pratik cepheyse insanın özgürlüğünü temsil eder. Teorik cephede insan, arzularına göre hareket eden bir aktördür ve parçası olduğu doğanın kurallarına zorunlu olarak uymak zorundadır. Kant’a göre, insanı hayvandan ayıran cephe olan pratik cephedeyse insan, usuyla hareket eder ve irade sahibidir. ${ }^{29}$ Isşte bu irade ve özgürlük sahibi olduğu cephe, insanın ahlak yasasını olanaklı hâle getirdiği alandır. $\mathrm{Bu}$ alanda eylem, doğadaki gibi bir etki-tepki formülüyle sınırlandırılamaz. Bu alanda yegâne ussal varlık olan insan, belli ilkelere ve yasalara uyarak eyler ve bu erdemli eylem de onu bir yandan hayvanlardan ayırırken, diğer yandan da ahlaklı kılar. ${ }^{30}$ İnsanın özgür olabilmesi için işte bu numenal dünyanın farkında olabilmesi, başka bir deyişle, us sahibi olması gerekmektedir. ${ }^{31} \mathrm{Bu}$ noktada Kant'ın görüşlerinin Marksizmle uyuştuğu çağrışımı ilk anda belirse de aslında bu fikir Marksizmin insan zihninin algıladığı ahlak yasalarının toplumsal bir kalıbın içinde şekillendiği görüşüyle neredeyse taban tabana zıttır. Çünkü Marksizm mevcut toplumu ve kuralları bir bağımsız değişken olarak algılayıp, insanları ve özellikle işçileri ona bağımlı olarak tasvir ederken; Kant, henüz insanların ahlaki ölçülere uygun hareket ettiği ve toplum sözleşmesine dâhil olduğu "amaçlar krallığının” kurulmadığını ifade etmiştir. ${ }^{32}$

Kant, ussal bir varlık olan insanı dünya üzerinde nevi şahsına münhasır bir özne olarak algılamıştır. Kant’ın insana biçtiği en önemli misyon, insan olma erdemine ulaşmaktır. Kant,

25 Immanuel Kant, Critique of Pure Reason, çev. Paul Guyer ve Allen W. Wood,

(Cambridge: Cambridge University Press, 2000), 168.

26 Manfred Kuehn, Immanuel Kant, 123.

27 Immananuel Kant, Pratik Aklın Eleştirisi, çev. Ioanna Kuçuradi, (Ankara: Türkiye

Felsefe Kurumu Yayınları, 2014), 3-4, 17-18.

28 Kant, Pratik Aklın Eleştirisi, 118.

29 Kuehn, Immanuel Kant, 20.

30 Lucien Goldmann, Kant Felsefesine Girişs, çev. Afşar Timuçin, (İstanbul: Metis, 1983) 24.

31 Kant, Ablak Metafiziğinin Temellendirilmesi, 64-65.

32 Kant, Gelecekteki Her Metafiziğge Prolegomena, 50. 
insanın bundan evla bir görevi olamayacağını beyan etmiştir. Kant, özgürlük ve ahlak yasasının vücut bulacağı yer olan amaçlar krallığının kuruculuğu görevini yüklediği pratik usun teorik usa karşı ahlaki üstünlüğünü savunur. ${ }^{33}$ Benzer bir bağlamda, koşulsuz buyruğun bir koşula bağlı olan buyruğa karşı üstünlüğüne de işaret eden Kant’ın koşula bağlı olarak tanımladığı ve insanların arzu-isteklerine ev sahipliği yapan kısmı koşullu buyruktur. ${ }^{34} \mathrm{Bu}$ alan, bir sonuca ulaşmak için bir eylemi yapma zorunluluğu olarak da ifade edilebilir. Örneğin, "Sosyalizme ulaşmak istiyorsanız, örgütlenin ve sınıf mücadelesi verin” böyle bir önermedir. Burada herkesin arzu ve isteklerinin farklılaşmasından kaynaklı olarak bir evrensel zorunluluktan bahsetmenin mümkün olmaması, onun üstün ilke olmasına engeldir. ${ }^{35}$ Buna karşın, insanın pratik usa dayanan yanı da koşulsuz buyruğa işaret eder. Başka bir ifadeyle, bir eylemi bir sonuca ulaştırmak için değil, sadece "iyi” ve ahlaki olduğu için yapma anlamına gelir ve bu bakımdan evrensel bir nitelik taşır. ${ }^{36}$ Burada bir sonuç beklenmediğinden, eylemin sonucuyla ilgilenilmez ve amacın iyi olması ahlakilik ölçütü olarak değerlendirilir. Buradaki örnek, "Sosyalizme ulaşmak istiyorsanız, örgütlenin ve sınıf mücadelesi verin" önermesinin aksine, yalnızca "Örgütlenin ve sınıf mücadelesi verin” şeklinde olabilir ve sonucunda sosyalizme ulaşılıp ulaşılmayacağı bu önermenin ilgi alanının dışındadır. Burada iyiyi istemenin başlıca kendisi iyidir ve bir sonucun öncülü olarak düşünülmez. ${ }^{37}$ Kant'in bu iyiye adanmışlık fikrini dayandırdığı destekse ödev ahlakı olmuştur. Kant’ın mihverine ahlakı yerleştirdiği felsefesinin başlangıç noktası ödevdir ve Kant, ödevden yasa kavramına erişmiştir. ${ }^{38}$ Ödev kavramının Kant'ın felsefesinde üstlendiği rol, iyiden tecrübeden azade bir evrensel ahlak yasasına ulaşmak için yegâne birleştirici olmasıdır. ${ }^{39}$ Koşullu buyruk içinde değerlendirilen her türlü eylem, ödev kavramının dışında kalırken; koşulsuz buyruğun içinde kalan her eylem ödev kavramına uygundur. Diğer bir deyişle, yapılan eylemlerin sonuca değil, ahlaki yasaya uygunluğuna, amacının iyiliğine bakılarak ödev ahlakına aykırı olup olmadığı test edilebilir. Ödev ahlakı Kant'ın ana sorusu olan "Kendi maksimimi herkes için bir evrensel yasa olarak isteyebilir miyim?” sorusuyla bağlantılıdır ve Kant'a göre eğer birey buna uygun eyliyorsa o eylem ahlaklıdır. Ahlak yasası, doğa yasaları gibi kaçınılmaz şekilde karşı çıkılamaz olmamakla beraber, özgür insana seslenen gereklilik yasalarıdır. Nitekim Kant’a göre, isteme eylemi gibi ödev ahlakı da a priori olan ustan gelmekle beraber, insan özgürleştikçe ödev ahlakı ön plana çıkmaktadır. ${ }^{40}$

\section{Kant'ın Siyaset Felsefesi ve Sosyal Demokrasi İlişkisi}

Aslında Kant’ın liberal bir düşünür olması başlı başına sosyal demokrasinin sosyalizmden kapitalizmle uzlaşır revizyonist bir çizgiye sapması bağlamında anlamlı görünürken, Kant’ın sosyal demokrasi açısından da felsefi açıdan da son derece önemli bir yeri vardır. Genellikle Bernstein'le özdeşleştirilen sosyal demokrasinin Marksizmin sınıf temelli toplumsal çözümlemesinden

33 A.g.e., 50-51.

34 J. K. Uleman, An Introduction to Kant's Moral Philosophy, (NY: Cambridge University Press, 2010), 67-68.

35 Kant, Ahlak Metafiziğinin Temellendirilmesi, 30.

36 Uleman, An Introduction to Kant's Moral Philosophy, 67.

37 Goldmann, Kant Felsefesine Giriş, 24.

38 Kant, Ahlak Metafiziğinin Temellendirilmesi, 69-71.

39 Demir, Kant Ablak Siyaset, 52.

40 A.g.e., 55. 
uzaklaşarak etik ilkeleri merkeze koyan, bireyin ahlaki statüsü ve haklarına vurgu yapan neoKantçı bir projeye dönüştürülmesi meselesini, Alman sosyal demokratları içinde Lassalle'in, İngiltere'deyse Fabianların düşüncelerine kadar götürmek gerekir.

İlk olarak Lasalle (1825-1864), Marx’'n kapitalist devletin çelişkiler sonucunda yıkılacağı, sonra sınıfların ortadan kalkacağı ve sonucunda da devlet denen mefhumun yok olacağıyla ilgili görüşlerine karşı çıkarak, devleti var olması gereken bir yapı olarak yorumlamıştır. Lassalle, henüz işçi hareketinin yeni filizlendiği bir dönemde, işçilerin haklarını demokratik yollarla ele geçirebileceklerine inanmış ve bunun için işçilere yol olarak Almanya’nın ulusal birliğini tamamlama ve ulus devletleşme sürecinde oynamaları gereken etken rolü göstermiştir. ${ }^{41} \mathrm{Bu}$ da aslında işçilere Kant'ın tüm insanlar için yaptığı toplumsal birlik için ahlaksal bir görev yükler. Lassalle de tıpkı Kant’ın yaptığı gibi, insanın amaç alındığı bir amaçlar cumhuriyeti fikrini desteklemiş ve amaçlar cumhuriyetinde insanlığın amaca evrilmesiyle beraber, ahlak yasası idealinin de bireysellikten toplumsallığa dönüşeceğine inanmıştır. ${ }^{42}$ Lassalle'in işçilere toplumun diğer üyeleriyle birlikte devletin kuruculuğuyla ilgili yüklediği misyon da yine kaynağını Kantçı yaklaşımdan alır. Kant’a göre de bireyin kamusal özne olarak sahneye çıkmasına dayanak oluşturacak bir amaçlar cumhuriyeti şemsiyesi altında yaşamak ussal bir davranıştır. ${ }^{43}$ Kant'ın amaçlar cumhuriyeti fikri; kişilerin, aynı zamanda çağdaş sosyal demokrasinin de ilkeleri olan özgürlük ve eşitlik gibi temel haklarının karşılıklı olarak garanti altına alındığı bir düzendir. Kant'a göre bu düzen, irade birliği, ödev ahlakı gibi erdemli davranışları yurttaşlar için karşılıklı birer zorunluluk haline getiren toplum sözleşmesinin de vücut bulmuş halidir. ${ }^{44}$ Lassalle de, iş̧̧ilerin daha kuruluşundan itibaren bu sözleşmenin eşit bileşenlerinden biri olarak, demokratik yollarla elde edebileceğine inanmıştır. ${ }^{45}$ Lassalle’i görüşleri bakımından Kant'a yaklaştıran bir diğer argümanı da kamusal alanla simbiyoz içinde bulunan demokrasiyi hayatta tutacak olan şeyin "zor" olduğuna olan inancı olmuştur. ${ }^{46}$ Nitekim Kant da hak, adalet, hukuk ve özgürlük gibi değerlerin vücut bulabilmesi için bir kamusal alana olan ihtiyaçtan bahsetmiş ve bu kamusal alanda eşitliğin bozulmaması için çeşitli sınırlamaların uygulanması gerektiğini de vurgulamıştır. Kant'a göre bu sınırlamaları uygulayacak yegâne güç, devletin zorudur. Kant, baskıyı onaylayan bu fikrini, "engellemenin engellenmesi” olarak meşrulaştırmıştır. ${ }^{47}$

Doğduğu günden beri sınıf siyasetine mesafeli duran Fabian Hareketi de bir yandan Kantçı ahlak ve etik yorumlarından etkilenirken, diğer yandan da yer yer onun siyaset felsefesinden faydalanmışlardır. Webb’lerin Kant'ın a priori anlayışına, "İki kere ikinin dört ettiğini anlamamız için dış dünyadan gelen bir deneyime muhtaç değiliz” açıklamasıyla yaptıkları övgü, onları

41 Sheri Berman, The Social Democrat Moment, (Cambridge: Harvard University Press, 1998) 72.

42 Kant, Gelecekteki Her Metafiziğe Prolegomena, 51-54.

43 Demir, Kant Ahlak Siyaset, 111.

44 A.g.e., 112.

45 Deniz Kavukçuoğlu, Sosyal Demokraside Temel Eğilimler, (İstanbul: Cumhuriyet Kitapları, 2003), 15.

46 Berman, The Social Democrat Moment, 72.

47 Demir, Kant Ahlak Siyaset, 144. 
Kant'a yaklaştırırken, aynı ölçüde de Marksizmden uzaklaştırmıştır. ${ }^{48}$ Her şeyden önce bir entelektüel kulüp niteliği taşıyan Fabian Topluluğu, toplumsal sorunları çözmenin en geçerli yolunun bilim yolunda ilerlemek olduğuna inanarak, Kant'ın ampirizmine yakın bir tutum sergilerken; özgür bireylerden oluşan bir entelektüeller kulübü niteliğiyle de Kant’ın rasyonalist düşüncesine yaklaşarak benzer bir senteze yönelmişlerdir. ${ }^{49}$ Nitekim Fabiancılar bu belirlemelere uygun olarak teorik olmaktan ziyade pratik ve deneyci olarak tanımlanmıştırlar. ${ }^{50}$ Kant'ın, Ortaçağ’’n dini etiğinin rasyonalize edilmiş hâli ${ }^{51}$ gibi ortaya sunduğu ahlak yasası da yine Fabiancıları Kant'a yaklaştıran niteliklerden biri olmuştur. Fabiancılar, Kant'ın bu anlayışına paralel, ancak rasyonalize edilmemiş bir hâlinin uzantısı olarak, İsa’nın dininin insancıl kardeşlik argümanına sarılmıştırlar. ${ }^{52}$ Fabiancıları Kant’a yaklaştıran bir diğer argümanları da onların sosyalizm anlayışlarının sosyalizmin daha toplumcu anlamına yakın bir kullanımı olması ve onu rasyonelleşmiş bir bireycilik olarak anlamlandırmaları olmuştur. ${ }^{53} \mathrm{Bu}$ bakımdan Fabiancılar, rasyonalizmi kendisinin dayanaklarından biri olarak seçen Kant'a bu manada da yaklaşırlar.

Londra'da kaldığı yıllarda Fabiancı etki altında kalan Bernstein' in de birçok görüşü Fabiancılarla aynı doğrultuda olmakla beraber o, tartışmayı daha da ileri bir noktaya taşımıştır. ${ }^{54}$ Bernstein, sınıf kavgasını tebliğ eden ve proletarya diktatörlügüne öykünen görüşlerini reddederken, bunun yerine, işçi sınıfının demokrasi dahlinde, Marksizmin karakteri gereği gerici bulduğu burjuva partileri de dahil olmak üzere tüm partilerle ittifaklar kurarak daha iyi bir yaşama ulaşabilecekleri inancını taşımıştır. ${ }^{55} \mathrm{Bu}$ inanç, Kant'ın rasyonel olarak ahlaki seçim yapan özgür bireylerin toplum sözleşmesine birbirlerine bağlı ve bağlayıcı şekilde dâhil olmaları inancına yakın bir inanç noktasına tekabül etmektedir. Diğer bir beyanla Bernstein'in görüşü, kapitalist sistemi sslah ederek, toplum sözleşmesini daha ehil hâle getirecek bir düşünce sistemidir. Bu noktada, Ortodoks Marksizm ve neo-Kantçı revizyonizm tartışmasını yürüten Kautsky ve Bernstein'in görüşlerinden bahsetmek gerekir.

20. yüzyılın başında parti, kooperatif ve sendikalar vasıtasıyla örgütlenen Alman sosyal demokratlarının günden güne güç kazanmasıyla beraber, örgüt içinde bir tartışma da ortaya çıkmıştır. Bir yanda kendisini gelecekte cebir yoluyla yapılacak bir devrime hazırlayanlar varken, diğer yanda bu kitleselliğin getirdiği güçten hareketle mevcut düzenin içinde yalnızca yarının değil bugünün emekçilerinin de hayatını daha iyi bir hâle getirebileceğini düşünenler ortaya çıkmıştır. İkinci grubun savunduğu görüşlerin başlangıç noktası, Bernstein’in ortaya

48 Mark Bevir, "Sidney Webb: Utilitarianism, Positivism, and Social Democracy," Journal of Modern History 70 (2002), 12.

49 Cenk Saraçoğlu, "Sosyal Demokrasi", Siyaset Bilimi: Kavramlar, İdeolojiler, Disiplinler Arası İlişkiler içinde, Der. Gökhan Atılgan ve E. Attila Aytekin, (İstanbul: Yordam, 2018), 367.

50 Anıl Çeçen, Sosyal Demokrasi, (Ankara: Devinim, 1984), 52.

51 Marcel Gauchet, La religion dans la democratie, (Paris: Gallimard, 1998), 47-50.

52 Çeçen, Sosyal Demokrasi, 55.

53 Donald Sassoon, One Hundred Years of Socialism: The West European Left in the Twentieth Century, (Londra: Tauris, 2010), 30.

54 Çeçen, Sosyal Demokrasi, 16.

55 Marius S. Ostrowski, Eduard Bernstein on Social Democracy and International Politics, (Oxford: Macmillan, 2018), 2. 
attığı revizyonizmle birlikte olmuştur. Bu görüşler, İkinci Enternasyonal'in Paris'te toplanan 1900 tarihli ilk toplantısında da tartışılmıştır. Bu tartışmayı başlatan, Bernstein’in revizyonist görüşleri kadar, Millerand'ın Fransa'da hükümete girmesi olmuştur. ${ }^{56}$ Millerand'ın Fransız hükümetinde yer alması, sosyalist geleneğin burjuva sınıfının bir baskı aracı olarak kodladığı ve bu yüzden yıkılması gerektiğini ifade ettiği devlet yönetiminde bir sosyalistin ilk defa yer alması anlamına gelmiştir. Kongreye göre, bir sosyalistin, Millerand'ın burjuva hükümetine alınmasının nedeni, sosyalist örgütlenmenin hızlı gelişmesi olmuştur. Bir başka ifadeyle, sosyalist hareketin yükselişinden endişe eden burjuvazi, tehlikede gördüğü özgürlüklerini korumak için pasifize etmek istediği sosyalist hareketten birini hükümete dahil etmiştir. ${ }^{57}$

İtalyan delegesi Enrico Ferri ve Fransiz delegesi Jules Guesde Ortodoks Marksizme ait argümanları tekrar ettikten sonra Guesde, her bileşen ülke hareketinden Millerand refleksiyle hareket eden biri çıkması durumunda, hükümet üyelerinin hükümetlerinin askeri harcamalarını onaylamakla yükümlü olmalarından kaynaklı olarak, Sosyalist Enternasyonal'in amacının ve varlı̆̆ının ortadan kalkacağını ifade etmiştir. ${ }^{58}$ Tartışmaların sürdüğü esnada Enternasyonal'in ana gücü olan Alman delegasyonu, ev sahibi Fransız delegasyonu arasındaki bölünmüşlüğü derinleştirmemek adına daha mutedil bir tutum sergilemiştir. Netice itibariyle Kautsky’nin okuduğu kararda, geçici bir istisnai önlem olarak sosyalistlerin burjuva hükümetlerine girebileceğini ifade edilerek revizyonistleri rahatlatırken, bunun yanında Millerand'ın bu kararı partisine onaylatmamasını kınayarak da ilerleyen süreçte bu tür bir eylemlerde bulunulmasının önüne geçmeye çalışmıştır. ${ }^{59}$ Ancak bu mutedil tavır, Alman sosyal demokratları arasındaki fikirsel ve örgütsel ayrılığı engelleyememiştir.

Alman sosyal demokratlarının revizyonizm ve devrimcilik bağlamında yaptıkları tartışma, Eduard Bernstein ve Karl Kautsky arasında cereyan etmiştir. Kautsky, Marx’ın artı değer görüşünü, kapitalizmin bunalımlardan kaçınılmaz krize ulaşacağı fikrini desteklemiştir. Diğer bir beyanla Kautsky, kapitalist sistemin işçilerin sürekli yoksullaştığı bir ortamda, sermayenin giderek sınırlı sayıda kişide toplanacağı görüşünü savunmuştur. Ona göre, bunun sonucunda üretim araçlarının sosyalleştirilmesi sosyalizme doğru bir yol açacaktır. ${ }^{60}$ Kautsky, sınıf tahakkümünün aracı olarak gördüğü devletin sosyalistlerce yıpratılması gerektiği fikrini savunurken, sosyal reformlar için bile olsa onunla uzlaşılmaması gerektiğinin altını çizmiştir. ${ }^{61}$ Bernstein ise Kautsky'nin aksine, Marx’’n kapitalizmin kaçınılmaz krizi ve çöküşüyle sosyalizme gidileceği fikrinin yanlışlandığını ifade etmiştir. Marx’ın beklentisinin aksine ne orta sınıf kaybolmuş ne de sınıf çatışmaları keskinleşmiştir. ${ }^{62}$ Bernstein, sermayenin de Marx’’n öngördüğü gibi giderek sınırlı kişide-grupta

56 James Joll, The Second International, (Londra ve Boston: Routledge \& Kean Paul, 1974), 94.

57 Joll, The Second International, 95.

58 A.g.e., 96.

59 A.g.e., 97.

60 George D. H. Cole, History of Socialist Thought, (New York: St. Martin’s Press, 1963), 267-268.

61 Karl Kautsky, The Class Struggle (Erfurt Program), çev. Willian E. Bohn, (Şikago: Charles H. Kerr \& Company, 1910), 35-36.

62 İsmail Cem, Sosyal Demokrasi Nedir, Ne Değildir: ... ve Türkiye’de Olabilirliği, (İstanbul: Cem Yayınları, 1984), 2627. 
toplanmadığını, hisse senedi gibi yollarla daha da yayıldığını söylemiştir. Bu yüzden sosyalizme kaçınılmaz bir krizin sonucu olarak değil, aşamalarla gidilebileceğini belirten Bernstein, nihai sonucun kaçınılmazlığı fikrine karşı çıkmıştır. ${ }^{63}$ Bu görüşleri, yukarıda belirtildiği şekliyle Kautsky tarafından eleştirilen Bernstein, bu eleştirilere Kant'ın koşulsuz buyruğunun bir uzantısı olarak, "iktisadi felaket” tezinin kendisi için hiçbir şey ifade etmediğini ve kendisi için toplumsal gelişme ve işçi sınıfının öz-hareketini kapsayan hareketin her şey olduğunu belirterek karşılık vermiştir. ${ }^{64}$

Ayrıca Bernstein, devletin bir tahakküm aracı olduğu ve bu yüzden mutlak suretle yıpratılması gerektiği fikrine de muhalefet etmiş ve işçilerin "nihai amaç" gibi gerçekleşmeyecek bir ütopya etrafında kenetlenmektense daha pratik amaçları için kenetlenerek ekonomik zorlukları ve sosyal güvencesizliklerini aşacak aksiyonlara girişmeleri gerektiğini belirtmiştir. ${ }^{65}$ Bernstein, bunun meşru siyasi zemin olan parlamento mücadelesine odaklanarak ve yerel yönetimlerde iktidar sahibi olarak gerçekleşeceğini belirtmiştir. Bu yolla, kapitalizmin hukuki ve iktisadi düzeninin ehlileştirilip, işçiler lehine adımlar atılabileceğinin altını çizmiştir. Daha açık bir ifadeyle Bernstein, anarşistler ve sosyalistler arasındaki ayrımı yok ettiğine inandığı şiddet yöntemini reddederek, meşru zemin içinde hareket etmenin sosyalistlerin sosyo-politik stratejileri açısından en uygun yöntem olduğunu vurgulamıştır. ${ }^{66} \mathrm{O}$, şiddete dayalı devrim yöntemini evrimsel bir yöntemle ikame ederek, daha uzun erimli ve barışçı bir mücadeleyi kabul etmiştir. Bu yüzden o, sosyal demokrat hareketin işçi sınıfına dayanan kitlesini iktidar amacına ulaşmak için nicel olarak yetersiz bulmuş ve parlamenter mücadelede söz sahibi olabilmek için liberal partilerle geçici ittifaklar kurulabileceğini savunmuştur. ${ }^{67}$ Çünkü Bernstein'in önceliği işçilerin sosyoekonomik refahını sağlamak gibi pratiktir ve bugünün amaçlarını da yerine getirir niteliktedir. Ayrıca Bernstein, Kant'ın devletlerin demokratik dönüşümüne duyduğu inanca paralel bu görüşlerinin yanında, sınıfsal uzlaşıyı öngören barışçı sosyal demokrat partilerin savaş gücünü korumasının da anlamı kalmadığını belirtmiştir. ${ }^{68}$ Bu noktada "vatansız proleter" fikrinin de ortadan kalktığını ve Kant'ın toplum sözleşmesine katkı sunma görevinin bir yansıması olarak, işçilerin artık ulusal devletlerin içinde birer vatandaş olduklarını ve ehlileştirilmiş bir demokraside, sosyal demokraside bunun daha da ideal bir forma bürüneceğini vurgulamıştır. ${ }^{69}$ Ancak Kautsky, işbirliğine yönelen bir sosyal demokrat harekette iş̧̧i sınıfının bu koalisyon içinde görünürlüğünü ve etkisini kaybedeceği inancıyla bu fikre karşı çıkmıştır, $\mathrm{O}$, sosyal demokrat partinin işçilerle özdeş ve homojen niteliğini koruması gerektiğini savunmuştur. ${ }^{70}$

Kautsky, önceliğini eşitsizliğin önüne geçmek, refahın yeniden dağıtılması gibi kavramlar olan revizyonistlerin bu tutumunu Kantçı anlamda ahlakçılığın bir uzantısı olarak görmüş, neo-Kantçı

63 Tanıl Bora, Almanya’da Sosyal Demokrasinin Doğuşu (1848-1913), (İstanbul: SODEV, 2004), 89.

64 Fazıl Sağlam, "Bernstein”, Sosyalist Siyasal Düşünüşs Tarihi Cilt I içinde, Der. Mete Tunçay, (İstanbul: Bilgi Yayınevi, 1976), 367-370.

65 Sağlam, "Bernstein", 86-87.

66 Eduard Bernstein, Evrimsel Sosyalizm, çev. Alkım Cerit ve Evren Bülaycı, (İstanbul: Kavram, 1991), $150-151$.

67 Cem, Sosyal Demokrasi Nedir, Ne Değildir: ... ve Türkiye’de Olabilirlĭgi, 86-87.

68 Bernstein, Evrimsel Sosyalizm, 124.

69 A.g.e, 124-125.

70 Cem, Sosyal Demokrasi Nedir, Ne Değildir: ... ve Türkiye’de Olabilirliği, 100. 
revizyonistlerin adalet ve eşitlik gibi mevcut burjuva toplumunun verili düzenini sslah etmeye yönelen kavramlarına karşı çıkmıştır. Çünkü ona göre, Bernstein'in kendini adadığı paylaşım adaleti meselesi, sosyalizmin özünü, üretim araçlarının el değiştirmesi fikrini iskalamıştır. ${ }^{71}$ Sınıfsal alanda Bernstein ve Kautsky'nin bir diğer çatışma alanları da köylülerle ilgili olmuştur. Bernstein, köylülerin lehine bir tarım politikasının da sosyal demokratlar tarafından savunulması ve çiftçilerin desteklenmesi gerektiğinin altını çizmiştir. Ayrıca böyle bir politikanın sonucunda çiftçilerin olumlu ya da olumsuz olarak etkilenmelerinin kendi ilgi alanının dışında olduğunu belirterek de Kant'in niyetin iyiliği ve ahlakiliğini önceleyen, sonuçla ilgilenmeyen koşulsuz buyruğunun paralelinde hareket etmiştir. ${ }^{72}$ Ancak Kautsky, Marx’ın görüşlerinin paralelinde bir tutumla, köylülerin proleter değil, aksine tepkici olduklarını ve onlarla bir işbirliğinin sosyalizmin terki anlamına geldiğini ifade etmiştir. ${ }^{73}$

Kautsky, Alman sosyalizm tartışmalarında etkili olan neo-Kantçılğa, Kant’’n etik anlayışını Marksizmle harmanlama ve bu vasıtayla Kant'ı sosyalizmin kurucularından sayma fikrine karşı çıkmıştır. O, Bernstein'in "Evrimsel Sosyalizm” başlıklı eserinde Kant'ı ikiyüzlülüğün panzehri olarak sunduğu ve Hegel diyalektiğini de sosyalist hareket içindeki bu ikiyüzlülüğe bir zemin hazırladığ1 fikrinden hareketle savunduğu neo-Kantçılığın karşısına materyalizmi koymuştur. ${ }^{74}$ Bernstein ise ilgili eserindeki "Kant Cant'a Karşı” bölümünde ele aldığı görüşlerde, İngilizce bir terim olan "Cant” $1 n$ ikiyüzlülük anlamına geldiğini söylemiştir. Bernstein, bu ikiyüzlülüğü, sosyalistler dâhil insanların geleneksel varsayımlara meydan okuyamadıkları için gelenekleri özünden farklı, kendi istedikleri doğrultuda içeriklendirmeleri olarak açıklamıştır. O, “özgürlük hareketi” olarak tanımladığı sosyalist hareketin mücadele biçimi olarak, önceden karar verilmiş bir hazır reçetenin her durumda uygulayamayacağını not etmiş ve hazır reçetede ısrar edenlerin zamanla kaçınılmaz olarak ütopyacılğa düşeceklerini belirtmiştir. O ayrıca, İngiltere'de kendisinin öngördüğü gibi işçilerin yasal yollarla ve demokratik düzen içinde yaşam koşullarının iyileştiğini söylemiş ve bunu ütopyacılığa düşmeyen devrimcilik olarak yorumlamıştır. Ona göre, işçi sınıfı, pratik amaçlarına hizmet etmeyen tüm kuram ve ilkeleri mutlaka terk edeceği için aslında revizyonist hareket, sosyalizmin kendisini de kurtarma hareketidir. ${ }^{75}$

Bernstein, Kautsky’nin aksine diyalektik materyalizmi reddetmiş ve bunun Hegel'den Marksizme miras kalan bir kambur olduğunu ifade etmiştir. Bu miras, sosyal demokrasiyi bir yandan spekülatif bir dünyaya iterek ütopyacılık riskine sürükleyip ampirik olguyu terk etmek, diğer yandan da şiddeti olumlamak gibi iki tehlikeye ittiğini belirtmiştir. Bernstein, Hegel’in bu köhnemiş fikirleri yerine Kant' 1 eleştirel yaklaşımının benimsenmesi gerektiğini ifade etmiştir. ${ }^{76}$ Bernstein, evrimin sürekli yeni güç sahiplerini ve yeni olguları getirmekte olduğunu ifade etmiştir. Bu yüzden, Marx’ın ortaya koyduğu görüşlerin yetersiz olduğunu ve bunun da evrimin önemini

71 A.g.e., 101-102.

72 Cole, History of Socialist Thought, 265.

73 John Vaizey, Çă̆ımızın Devrimleri: Sosyal Demokrasi, çev. Ahmet Gazioğlu, (İstanbul: Efes Yayınları, 1974$), 47$.

74 Karl Kautsky, Seçilmiş Politik Yazılar, çev. Celal Kanat, (İstanbul: Kavram Yayınları, 1990), 45.

75 Bernstein, Evrimsel Sosyalizm, 141-144.

76 Cole, History of Socialist Thought, 294-297. 
küçük gösterdiğini vurgulamıştır. ${ }^{77}$ Ancak mevcut çağda sınıflar-arası bir çatışma yaşanmasının zorunlu olmadığını belirten Bernstein, sınıfsal bir uzlaşmanın ve devletin demokratik yollarla dönüştürülmesinin mümkün olduğunu belirtmiştir. ${ }^{78}$

Ahlak alanına gelindiğinde, Kautsky’e göre ahlaki standartlar, toplumla aynı şekil ve ölçüde olmasa da toplumsal değişimle beraber değişime uğrar. Bunlar, norm hâline evrildiğinde ise, tüm üstyapı kurularında olduğu gibi, üretim tarzı gelişimi ve buna bağlı olarak sosyal gereksinimlerin değişiminin aksine bir süre bunlardan bağımsız bir şekilde varlığını sürdürebilirler. Bu geçici bağımsız varoluş hâli, Marksizmin egemenliğine karşı koyamayanlar (revizyonistler) tarafından Kant'ın tinine (geist) sığınmak için bir sebep olmuştur. Onlar, buradan hareketle tin ve ekonominin birbirini karşılıklı olarak etkilemesi ve bir yandan beraberce toplumsal gelişimi kontrol ederken, diğer yandan da eşgüdümlü olarak ilerlemeleri anlamına gelen etkileşim ilkesine yaslanmıştırlar. Diğer bir ifadeyle, kapitalist sistemin ıslah edilmesine bireyin muktedir olduğunu düşünmüştürler. Kautsky’ e göre, çelişkiler çözülse dahi, bu mevcut üstyapıyı düzenlemek anlamına gelir ve bu durumda yeni bir üstyapı kurulamaz. Ayrıca ahlaki normlar, bağımsız hâle evrildikleri andan itibaren katı ve statükocu bir duruma geldikleri için yeni çelişkilere muhtaç olan ilerlemeyi de durdururlar. ${ }^{79}$ Bernstein'in anlayışında sınıf kavgasından anlaşılması gereken iş çevreleriyle iş̧̧iler arasında zorunlu olarak yürütülmesi gereken bir kavga olmamıştır. Onun anlayışına göre, işçi sınıfının ahlaki ve entelektüel birikimini geliştirmesi asıl kavgadır ve işçilerin yurttaşlık mertebesine yükselebilmesi için bunun sağlanması şarttır. ${ }^{80}$ Çünkü Bernstein’e göre, eğitimsiz bir iş̧̧i sınıfından sosyal adaleti sağlayacak ve toplum sözleşmesini daha ehil hâle getirecek bir entelektüel ve ahlaki seviyeye sahip olması beklenemez. ${ }^{81}$ Bernstein'in bu görüşleri, Kant' ın ödevi ahlaki bir yasa olarak gören ve eylerken eyleminin evrensel bir yasa gibi, tüm insanlar için geçerli olabilecek şekilde eyleyebilen bireyin ancak özgür bir birey olabileceği anlayışıyla örtüşür. ${ }^{82}$ Kant’ın bireyin rasyonel bir varlık olmasından kaynaklandığına inandığı özgürlük anlayışına, Bernstein de bireysellik duygusunun ancak özgürlük içerisinde gerçekleşebileceğine olan inancı vurgulamasıyla destek vermiştir. ${ }^{83}$ Bu iki felsefe, birbirini tamamlayıcı niteliktedir çünkü Kant'a göre de bireyin özgürlüğünün kısıtlanması kabul edilemez ve bu ahlaki ilkeye de aykırıdır. Kant, devletin dahi bireyin özgürlüğü için araçsal bir anlamı olduğunu vurgulamıştır. ${ }^{84}$

Kautsky'e göreyse bireye indirgenmiş ahlak ve bireyin çatışan ihtiyaçları, ilkel toplumlarda da su yüzüne çıkabilse de sınıfların ortaya çıkışıyla beraber bu çatışmalar daha problematik bir hâl almışlardır. Ancak sınıflı toplumlar ve sınıfsız ilkel toplumlar arasındaki temel fark, sınıfsız toplumların zora başvurulmadan yönetilebilir olmasıdır. Çünkü bu toplumlarda tikel çıkarlar mutlaka birbirini etkileyeceğinden, tikel çıkarlar ve dolayısıyla tikel ahlaki normlar da korunabilir.

77 Bernstein, Evrimsel Sosyalizm, 146.

78 Cem, Sosyal Demokrasi Nedir, Ne Değildir: ... ve Türkiye’de Olabilirlĭgi, 60-61.

79 Kautsky, Seçilmiş Politik Yazılar, 48.

80 Bernstein, Evrimsel Sosyalizm, 148.

81 A.g.e, 152.

82 Kant, Ablak Metafiziğinin Temellendirilmesi, 18.

83 Bernstein, Evrimsel Sosyalizm, 93.

84 Demir, Kant Ahlak Siyaset, 142. 
Ancak sınıflı toplumlarda ahlak, egemen sınıfın bir baskı aracı hâline geldiği için burada tikel ahlaki normlar değil, egemen sınıfların çıkarına hizmet eden ahlaki normlar egemendir. Bu yüzden sınıflı toplumlarda egemen sınıfların kazanılmış hakları ancak cebir yoluyla ellerinden alınabilir. ${ }^{85}$ Nitekim sınıflı toplumlarda ahlak ve ödev bilincini veren toplum değil, vicdandır. Başka bir ifadeyle, sınıflı toplumlarda çoğunluğun görüşüne ya da ahlaki normlarına karşı, sınıf bilinciyle ya da sınıf çatışmasının etkisiyle isyan ederek bu hâkim normlara karşı hareket edilebilir. Bu yüzden sınıflı toplumlarda hapis ve işkence gibi yaptırımların sınıf refleksiyle hareket etmekten çok daha az etkili olduğu gözlemlenebilir. Kautsky’e göre bunlara katlanmak, "utanca ve aşağılanmaya" maruz kalmaya tercih edilirler. ${ }^{86}$ Kautsky, sınıfsız toplumlardaki eski dinlerde ahlak ve kutsallar arasında bir bağ olmadığından bahsederken; sınıflı toplum inanışlarında ahlak, tanrı ve ahiret yaşamı arasında simbiyotik bir ilişki kurulduğunu belirtmiştir. Bunun sebebinin sınıfsı toplumlarda bireyin, toplum tarafindan kamuoyu vasıtasıyla kontrol altına alınabileceğini belirterek açıklayan Kautsky, sınıflı toplumlarda ise çatışmanın toplum ve birey arasında değil; sınıflar-arasında olmasından kaynaklı olarak kamuoyu baskısının mümkün olmadığını belirtmiş ve bu yüzden de egemen sınıfın, fiziksel şiddet ve ekonomik güce, bunları korumak ve meşrulaştırmak için de kiliseye, güvenlik güçlerine ve hukuka ihtiyaç duyduğunu ifade etmiştir ${ }^{87}$

Bernstein ise burjuvazinin işçilerin konsantrasyonunu odağından kaydırarak onları hegemonya araçlarıyla sömürdüğünü iddia eden ve sosyal demokrat partileri; işçilerin partisi, iş̧̧ileri örgütleyecek parti olarak gören Marksistlerin aksine, sivil toplumun kimse tarafından tahrip edilmeyeceğini iddia etmiştir. Bernstein, sosyal demokratların amacının salt bir işçi partisine dönüşmek ya da işçileri proleter olarak kodlayıp onları bulundukları toplumsal katmana hapsetmek olmadığını ifade ederek, onların amacının aynı zamanda işçileri de yurttaşlık mertebesine ulaştıracak bir evrensel yurttaşlı̆̆ $\mathrm{Bu}$ evrensel yurttaşlık tanımı ve iyi olana yönelme anlayışının da Kant’’n iyiliğin evrenselliği ve amaçlar cumhuriyeti fikirleriyle paralellik gösterdiği söylenebilir. Ayrıca Bernstein’in burada burjuva devletine karşı bir isyan noktasından hareket eden Marksizmden koparak, onun yerine devleti ehil, iş̧̧iyi yurttaş hâline getirmeye amaçlayan görüşleri de yine Kantçı felsefenin izlerini taşımaktadır. Çünkü Kant da bir yerde devlete karşı isyan etmenin müesses nizamı bozarak kaosa sebep olacağını söylerken, diğer yandan da örneğin Fransız Devrimi'ni olumlayarak bir paradoksun içine düşmüş gibi görünmektedir. ${ }^{89}$ Ancak insan haklarının tahribata maruz kaldığ 1 bir despotik rejimde, ayaklanma Kant'a göre de meşru olarak algılanabilir. ${ }^{90}$ Bernstein de işçilerin ayaklanma ihtimaline karşı daha mutedil bir noktaya gelen burjuva demokrasisinde, toplum sözleşmesine yurttaşlık bağlamında işçileri dahil ederek, ayaklanma olmadan, müesses nizamı revize ederek, herkesin özgürlügüne ve haklarına riayet edilen bir ülkenin barışçıl yollarla da

85 Kautsky, Seçilmiş Politik Yazılar, 48.

86 A.g.e., 48-49.

87 A.g.e., 49.

88 Bernstein, Evrimsel Sosyalizm, 113.

89 Demir, Kant Ahlak Siyaset, 146.

90 Arendt, "Kant'ın Siyaset Felsefesi Üzerine Notlar", 347. 
kurulabileceğine inanmıştır. Bernstein'in bu inancı, onun görüşlerinden esinlendiği Kant'ın bir çelişkisini de çağın gereklerini göz önünde bulundurarak çözmüştür.

Kautsky, Kant'ın 'kategorik imperative'ini kapitalist toplumlarda kişinin eylemlerini şekillendiren bir evrensel yasa olduğuna yaptığı vurgu nedeniyle fazla kuramsal, pratikten uzak ve olanaksız bulmuştur. $\mathrm{O}$, bunun nedenini çok biçimsel olması ve kendisini bireyin iyi niyetine dayandırması olarak açıklamıştır. Kautsky, salt usun temel yasası gibi bir evrensel yasanın geçerli olmasının ancak bireyin arzularının özgürce şekillenmesiyle mümkün olduğunun altını çizmiştir. Bu bağlamda Kant'ın çatışmayı bireyler bazında ve toplumsal olanla toplumsal olmayanın çatışması olarak görmesi, sosyal çatışmanın bireyin isteklerinden bağımsız geliştiği noktasını ıskalamasına neden olmuştur. Başka bir deyişle Kautsky, çatışmanın yalnızca bireysel çıkarlar ve toplumsal çıkarlar arasında değil, sınıflar-arasında cereyan ettiğinin altını çizmiştir. Ona göre, etik temel yasası, bireysel iyinin yerine toplumsal iyinin tercih edilmesi olarak anlaşılacaksa bu, Kant ve sosyalistleri ortaklaştırırdı. Çünkü genel etik yasası, toplumun gözlemlenmesi üzerinden ortaya çıkartılmaktadır. Buna karşın Kant ve neo-Kantçı revizyonistler ise öncesiz-sonrasız, tüm deneyimlerden tecrit edildiğini iddia ettikleri bağlayıcı bir ahlak yasasından bahsetmiştirler. Onlara göre bu yasa, üzerinde olduğu deneyim tarafından bozulmadığından saf bir zorlayıcı güç niteliği taşımaktadır.

Bu bağlamda Kautsky, Kant' ın toplumu bir bireyler toplamı olarak algıladığını ifade etmiştir. Dolayısıyla Kant, insanların etkileşimlerini iyi ya da kötü niyetlerine ve isteklerine bağlamıştır. ${ }^{91}$ Kautsky’e göre Kant, toplumun işbölümü ve işbirliğine dayanan bir organizma olduğunu ve dolayısıyla etkileşimin de kendi istek ve niyetinden bağımsız olarak da gelişebildiğini kavrayamamıştır. Bu da onun işbölümü dolayısıyla oluşan meslekler arasındaki bağımlılık ilişkilerini görememesine sebep olmuştur. İşbölümüne dayalı bu bağımlılık, burjuva toplumu içinde önce çıkar, sonra da sınıf çatışmasına dönüştüğünden Kant ve neo-Kantçı revizyonistlerin birey odaklı bakışları bu noktayı gözden kaçırmıştır. ${ }^{22}$ Bernstein ise sosyal demokrasinin burjuva ahlakı yüzünden bir esaret değil, daha fazla özgürlük yaratacağını, ancak bu özgürlüğün anarşist ideolojinin algıladığı gibi; bireyin topluma karşı tüm sorumluluklarından azledilmiş biçimde değil, özgür iradelerine ket vuran tüm engellerden kurtarılmasıyla mümkün olacağını belirtmiştir. Bireylerin hem özgür bireyler olup hem de birbirlerinin özgürlük alanlarını kısıtlamayacakları yöntemi de Bernstein, toplumsal örgütlenme olarak açıklamıştır ve onu Kant'a en çok yaklaştıran tanımlamasını yaparak sosyal demokrasiyi, “örgütleyici liberalizm” olarak açıklamıştır. ${ }^{93}$ Kant da toplum sözleşmesini doğal hakkın kamusal hakka evrilmesi süreci olarak yorumlamış ve rasyonel özgürlük temelli bir organizasyondan bahsetmiştir. O da Bernstein'in iddia ettiği gibi, böylesi büyük bir rıza örgütlenmesinin vücut bulabileceği yegâne sivil toplum aygıtını devlet olarak görmüştür. ${ }^{94}$

91 Kautsky, Seçilmiş Politik Yazılar, 59.

92 A.g.e., 59-60.

93 Bernstein, Evrimsel Sosyalizm, 116.

94 Immanuel Kant, Ebedi Barı̧̧ Üzerine Felsefi Deneme. çev. Yavuz Abadab ve Seha Meray,( Ankara: Ankara Üniversitesi Siyasal Bilgiler Fakültesi Yayınları, 1960) 
Kautsky’e göre, kuşkucu olduğunu iddia edip Marksistleri sekterlikle suçlayanların ahlaki normların insanın üzerindeki iktidar ilişkileri tarafından topluma çeşitli yollarla empoze edilmeyip, Kantçı manada bir tercih ürünü olduklarında ısrar etmelerinin asıl kendisi bir sekterlik hâline gelmiştir. O, "Kuşkuculuk, zorunluluğun kabulünden nasıl doğabilir?” sorusuyla ahlakın insan seçiminin bir ürünü olduğunda ısrar edenlerin kuşkuculuk iddialarını sorgulamıştır. ${ }^{95}$ Kantçı felsefede kategorik imperative, doğa ve toplumun üzerinde adeta bir rasyonel tanrıça yaratmıştır. Dolayısıyla mutlak bir ahlak fikrini benimseyen neo-Kantçı revizyonistler de benzer bir sorunla karşı karşıyadırlar. Çünkü mutlak ahlak fikrinin kaçınılmaz dayanağı metafizik bir ögeye yaslanmaktır. Daha açık bir ifadeyle, kuşkuculuk adına Kant felsefesini öne çıkaran revizyonistler, hem muğlak bir metafiziğe hem de mevcut sınıflı toplumda hangi ahlak anlayışının "değerli" ahlak anlayışı olduğu konusunda bir belirsizliğe düşmüştürler. Bu muğlaklıktan kaynaklı olarak, mevcut burjuva ahlakının 'evrensel hukuk sistemi' iddiası dolayısıyla bu ahlak biçimi toplumu teröre iten proleter ahlak anlayışına tercih edilebilecekken; aksine, sosyalizmin kaçınılmaz olduğunu gören bir kişi de proleter ahlakı daha üstün sayabilir. Ancak burada önemli olan nokta, revizyonistlerin iddia ettikleri gibi neo-Kantçı felsefi temelin, toplumu zorunlu olarak sosyalizme, sosyal demokrasiye götüreceği iddiasının Kautsky tarafından birbiriyle çatışan bu iki yönü gösterilerek yanlışlanmaya çalışılması olmuştur. ${ }^{96}$ Kautsky’e göre, Neo-Kantçı revizyonistlerin bu muğlak tutumlarına karşı, önceliği iktisadi çelişkilere veren ve bu alanda net bir duruşu olan Marksizmin ahlak anlayışı nettir ve proleter olandan yanadır. Bu yüzden Kautsky’e göre, onların ahlak alanındaki bu muğlaklıkları, aslında sosyalist iktisadi anlayıştan ayrılmalarının doğal bir sonucu olmuştur. $\mathrm{O}$, sosyalizmi hayattan değil, masa başında okuduklarından öğrenmiş olanların sosyalistliklerinin dayanağının Kant olmasının mümkün olmadığını ifade etmiş ve bu dayanağın Marx'ın zengin literatürü olduğunu hatırlatmıştır. ${ }^{97}$

Bernstein ise Kant'ın kendisine ettiği rehberliği ve ona öykünmesinin sebebini, biraz da dönemin, Kautsky dahil, Ortodoks Marksistlerine karşı iğneleme maksadıyla, "Bizim önderlerimizin yaptıklarından hangisinin değerli olduğunu ve yaşayacağını, neyin yok olacağını ve yok olması gerektiğini açıkça görebilen bir düşünür (...)"98 olarak tanımlarken, kendi revizyonist felsefesine olan katkısını da uğrunda mücadele edilmesi gereken ilkelerin belirlenmesinde daha objektif kararlar verebilmesi için vazgeçilmez bir düşünür olduğunu vurgulamıştır. ${ }^{99}$

\section{Sonuç}

Bu çalışmada, sosyal demokratların Marksist perspektiften Kantçı perspektife doğru yönelişleri ve Kantçı perspektifi kendi sol anlayışları içinde sentezlemeleri tartışılmıştır. 18. yüzyıla ve ardıl çağlarına damgasını vuran Kantçı felsefenin ana hatları olan özgürlük, eşitlik, etik ve adalet gibi kavramlar, sosyal demokrat önderleri etkilemiş ve onları yeni bir paradigma arayışına itmiştir. Ortodoks Marksizmin mevcut ahlakı bir burjuva dayatması olarak gören görüşüne karşın sosyal demokratlar, özgür insanın usunda şekillenen Kantçı ahlak anlayışına yaklaşmıştırlar.

95 Kautsky, Seçilmiş Politik Yazılar, 61.

96 A.g.e., 62-63.

97 A.g.e., 63.

98 Bernstein, Evrimsel Sosyalizm, 153.

99 A.g.e, 153. 
Sosyal demokratlar, uzun yıllardır Ortodoks Marksistler tarafından revizyonist olmakla suçlanmaktalardır. Revizyonizm tartışması, özellikle Keynesci ittifakın dağılmaya ve neoliberal politikaların yükselmeye başladığı 1980 sonrası dönemde pejoratif bir niteliğe bürünmüş ve sosyal demokratlar, Ortodoks Marksistlere karşı psikolojik üstünlüklerini görece kaybetmişlerdir. Ancak geçmişe dönüp bakıldığında revizyonizm meselesi bir zorunluluk olarak ortaya çıkmamış, aslında tam da Kant'ın öngördüğü gibi özgür iradenin bir seçimi olarak tercih edilmiştir. Ayrıca pejoratif anlam kazanan revizyonizm kavramı da Bernstein tarafından açık yüreklilikle ve olumlu bir anlamda kullanılmıştır. Ortodoks Marksizmin öngördüğü gibi bir proleter diktatörlüğün ahlakiliğini de sorgulamaya giden sosyal demokrat önderler, burjuva demokrasisinin daha ehil bir hâle evrilebileceği inancıyla Kant'ın amaçlar cumhuriyeti üst-felsefesine yaklaşmıştırlar. Ortodoks Marksizmin zorla ele geçirmeye çalıştı̆̆ 1 iktidarın da bir tahakküm aracına dönüşeceğine olan inançla revizyonistler, devletin özgürlükleri koruyacak bir araç olarak demokratik yollarla ele geçirildikten sonra toplum sözleşmesi dahlinde işçiler de dahil olmak üzere herkesin yurttaş olarak sayıldığı bir özgürlükler cumhuriyetini hedeflemiştirler.

Bu rejimde özgürlüklerin teminatı olarak görülen devlet, yalnızca özgürlükleri korumak için değil, sosyal adaleti sağlamak için de sisteme müdahale edebilecek ve kamulaştırmalar vasıtasıyla da tekelleşmelerin önüne geçebilecek bir kurum olarak kurgulanmıştır. Diğer bir ifadeyle aslında, zor kullanımı açısından Kant’a yaklaşan revizyonistler, kamulaştırma ve tekellerin kırılması fikirleriyle de hâlâ Marksist görüşlerin etkisinde bir görüntü çizmiştirler. Bu bağlamda, liberalizm ve Marksizm arasında bir yere hapsedilen sosyal demokrasiyi; liberal düşünceyle bireysellik yerine öncelediği yurttaşlık gibi fikirlerle ayrışan Kant’a yakınlığı ve Marx’ın diyalektiğinden kendini soyutlasa da refahını arttırmak için öncelediği kitlenin hâlâ işçiler olması bakımından Kant ve Marx arasında bir yerde değerlendirmek de mümkün gözükmektedir.

\footnotetext{
Hakem Değerlendirmesi: Dış bağımsız.

Çıkar Çatışması: Yazar çıkar çatışması bildirmemiștir.

Finansal Destek: Yazar bu çalışma için finansal destek almadığını beyan etmiştir.

Peer-review: Externally peer-reviewed.

Conflict of Interest: The author has no conflict of interest to declare.

Grant Support: The author declared that this study has received no financial support.
}

\section{Kaynaklar / References}

Althusser, Louis. Marx İ̧̧in. Çeviren. Iş̧ı Ergüden. İstanbul: İthaki Yayınları, 2015.

Arendt, Hannah. "Kant'ın Siyaset Felsefesi Üzerine Notlar." Çeviren. Yasemin Tezgiden Cogito41-42 Sonsuzluğun Sinirinda: Immanuel Kant, (2005), 340-380.

Berman, Sheri. The Social Democrat Moment. Cambridge: Harvard University Press, 1998.

Bernstein, Eduard. Evrimsel Sosyalizm, Çeviren. Alkım Cerit ve Evren Bülaycı, İstanbul: Kavram, 1991.

Bevir, Mark. "Sidney Webb: Utilitarianism, Positivism, and Social Democracy". Journal of Modern History 70, (2002), 2-62. 
Brenkert, G.George. Marx’ın Özgürlük Etiğgi, Çeviren. Yavuz Alogan, İstanbul: Ayrıntı Yayınları, 1998.

Bora, Tanıl. Almanya'da Sosyal Demokrasinin Doğuşu (1848-1913), İstanbul: SODEV, 2004.

Çeçen, Anıl. Sosyal Demokrasi. Ankara: Devinim, 1984.

Cem, İsmail. Sosyal Demokrasi Nedir, Ne Değildir: ... ve Türkiye’de Olabilirliği, İstanbul: Cem Yayınları, 1984.

Cole, George . D. H. History of Socialist Thought, C. III, New York: St. Martin's Press, 1963.

Demir, Aysel. Kant-Ahlak-Siyaset. Ankara: Siyasal Kitabevi, 2020.

Engels, Friedrich ve Marx, Karl. Felsefe İncelemeleri, Çeviren. Cem Eroğul, İstanbul: Yordam, 2017.

Fincanc1, Yurdagül. Günümüzde Sosyal Demokrasi. İstanbul: TÜSES, 1993.

Gauchet, Marcel. La religion dans la democratie, Paris: Gallimard, 1998.

Goldmann, Lucien. Kant Felsefesine Giriş. Çeviren. Afşar Timuçin, İstanbul: Metis, 1983.

Joll, James. The Second International, Londra ve Boston: Routledge \& Kean Paul, 1974.

Kant, Immanuel. Ebedi Barı̧s Üzerine Felsefi Deneme. Çeviren. Yavuz Abadab ve Seha Meray, Ankara: Ankara Üniversitesi Siyasal Bilgiler Fakültesi Yayınları, 1960.

Kant, Immanuel. Ahlak Metafiziğinin Temellendirilmesi, çev. Ioanna Kuçuradi,

Türkiye Felsefe Kurumu: Ankara, 1994.

Kant, Immanuel. Gelecekteki Her Metafiziğe Prolegomena, Çeviren. Ionna Kuçaradi ve Yusuf Örnek, Ankara: Türkiye Felsefe Kurumu Yayınları, 1995.

Kant, Immanuel. Critique of Pure Reason, Çeviren. Paul Guyer ve Allen W. Wood, Cambridge: Cambridge University Press, 2000.

Kant, Immanuel. Pratik Aklın Eleştirisi, Çeviren. Ioanna Kuçuradi, Ankara: Türkiye Felsefe Kurumu Yayınları, 2014.

Kamalak, İhsan. "Sosyal Demokrasiyi Tanımlamak: Eduard Bernstein’in Yaklaşımı Üzerinden Bir Deneme İlkeleriyle Sosyal Demokrasi." Sosyal Demokrasi Okumaları. Derleyen İbrahim Sarıtaş, 3-22. Ankara: Orion, 2012.

Karatani, Kojin. Transkritik Kant ve Marx Üzerine. Çeviren. Erkan Ünal, İstanbul: Metis, 2017.

Kautsky, Karl. The Class Struggle (Erfurt Program), Çeviren. Willian E. Bohn, Şikago: Charles H. Kerr \& Company, 1910.

Kautsky, Karl. Seçilmiş Politik Yazılar, Çeviren.. Celal Kanat, İstanbul: Kavram Yayınları, 1990.

Kavukçuoğlu, Deniz. Sosyal Demokraside Temel Eğilimler (3. bs.). İstanbul: Cumhuriyet Kitapları, 2003.

Kuehn, Manfred. Immanuel Kant. Çeviren. Bülent Doğan, İstanbul: Türkiye İş Bankası Kültür Yayınları, 2011.

Lefebvre, Henri. Sosyalist Dünya Görüşü: Marksizm, Çeviren. Doğan Görsev, İstanbul: Yordam, 2014.

Ostrowski, Marius. S. Eduard Bernstein on Social Democracy and International Politics. Oxford: Macmillan, 2018.

Peffer, R. G. Marksizm, Ablak ve Toplumsal Adalet, Çeviren. Yavuz Alogan, İstanbul: Ayrıntı Yayınları, 2001.

Sağlam, Fazıl. "Bernstein.” Sosyalist Siyasal Düşünüş Tarihi, C. I Derleyen. Mete Tunçay, İstanbul: Bilgi Yayınevi, 1976.

Saraçoğlu, Cenk. "Sosyal Demokrasi." Siyaset Bilimi: Kavramlar, İdeolojiler, Disiplinler Arası İlişkiler. Derleyen. E. Atilla Aytekin ve Gökhan Atılgan. 363-378, İstanbul: Yordam, 2018.

Sassoon, Donald. One Hundred Years of Socialism: The West European Left in the Twentieth Century. Londra: Tauris, 2010.

Uleman, J. K. An Introduction to Kant's Moral Philosophy. NY: Cambridge University Press, 2010.

Vaizey, John. Çă̆ımızın Devrimleri: Sosyal Demokrasi, Çeviren. Ahmet Gazioğlu, İstanbul: Efes Yayınları, 1974. 